\title{
Research on the Operational Performance of the First Batch of Private Banks in China
}

\author{
Peishen $\mathrm{CaO}^{1}$, Hongwei Liu ${ }^{1, *}$ \\ ${ }^{1}$ International Business School, Shaanxi Normal University, Xi'an, Shaanxi China \\ *Corresponding author. Email: $1021150301 @$ qq.com
}

\begin{abstract}
After nearly six years of exploration and development, China's first batch of private banks have gradually matured. In order to reflect the real development situation of the pilot private banks comprehensively, explore the advantages and disadvantages of the banks' operation, and help the banks to improve their own operation level, this paper evaluates the operational performance level of the first five pilot private banks. Based on the data of each bank from 2015 to 2019, this paper conducts a comparative study on the operational performance level of each bank by using Factor Analysis. The results show that Wenzhou Minshang Bank ranks the top in the overall operational performance level by virtue of its high loan quality and strong profitability;Meanwhile, as the non-performing loan ratio of We-Bank is increasing year by year and the profitability of Zhejiang Minshang Bank is weakening, the overall operational performance of the two banks is low. According to the research results, this paper provides feasible suggestions for the follow-up development of pilot private banks.
\end{abstract}

Keywords: Private Bank, Operational Performance, Factor Analysis

\section{INTRODUCTION}

In order to solve the financing problems of agriculture and micro business, government stressed the need to speed up the construction of private financial institutions, and put forward the strategic requirements of "promoting the establishment of private banks by qualified private capital" in the Third Plenary Session of the 18th CPC Central Committee. In 2014, the CBRC carried out the pilot work of private banks. In 2015, all the first batch of private banks were operating.

Private banks play an important role in solving the financing problems of agriculture and micro business. Although China's private banks were established late, they have grown rapidly. After nearly six years of exploration and development, China's first batch of private banks have been relatively mature. But what is the real development of these banks? What is the level of their performance? Which factors have a significant impact on the performance of these banks? This paper will discuss the above problems.

\section{LITERATURE REVIEW}

At present, Chinese scholars hold different attitudes towards the development of private banks. Wang Gang and Wu Fei (2016) believe the development of China's private banks is far from the market expectation through investigation and analysis[1]. However, Zhao Wenjing (2020) thinks that China's private banks have achieved great results in a short period of time[2]; Li Lihua (2020) thinks private banks have good development prospects, and explores the future development mode of private banks[3]. In addition, some scholars believe that the development of China's private banks is still facing many difficulties. Li Hao (2019), Xu Yishan (2020) and Liu Yu (2020) respectively analyzed the development, financing, and risk management of private banks, and gave feasible countermeasures[4-6].

The methods used to study the performance of banks are different. Serpil et al. (2005) and Liu Xiaolei (2018) selected Factor Analysis to analysis the performance of banks [7-8]. Susan et al. (2011) thought EVA had more advantages in performance evaluation [9]. Jelena and Evelina (2012) used the financial index evaluation method to study[10]. Barak et al. (2012) used DEA to study the operating performance of Canadian banks[11].

Through literature review, we found there are more theoretical studies on private banks in China, and few literature evaluate the actual development of private banks based on data. In order to make up for the lack of 
existing research, considering the applicable conditions of different methods and the availability of sample data, this paper uses the factor analysis to study the operating performance of the first batch of private banks.

\section{DEVELOPMENT STATUS OF THE FIR- ST BATCH OF PRIVATE BANKS}

The first batch of private banks include We Bank, Wenzhou Mingshang Bank, Tianjin Jincheng Bank, Zhejiang E-Commerce Bank and Shanghai Huarui Bank. For the convenience of analysis, we refer to the above banks as WB, WMB, TJB, ZWB and SHB.

\subsection{Market positioning}

The first batch of pilot private banks are mainly distributed in the economically developed areas of China. The regional differences make the service groups of banks have significant regional characteristics. However, the market positioning of the five banks is common. They mainly provide financial services for local agriculture and micro business to support the development of local real economy.

\subsection{Business model}

As the shareholders of WB and ZWB are Tencent and Alibaba, WB and ZWB use the Internet technology and resource advantages of shareholders and choose the pure internet mode for operation. This business model can reduce the service cost of the bank and improve the service efficiency. Although the shareholders of the other three banks are local leading enterprises, their business model is similar to that of traditional banks. They set up business outlets and websites to provide customers with online and offline services.

\subsection{Operating performance}

According to the annual reports from 2015 to 2019, the five private banks have shown strong growth ability, and the overall operating conditions are better.

Firstly, the scale of operation has maintained a rapid growth, and the scale of assets and loans has achieved a double growth trend. Among them, the average growth rate of assets of each bank is higher than 18\%. In 2019, the total assets of WB were 291 billion yuan and the average growth rate were $175 \%$. The total loans of WB banks have reached 100 billion level. Although TJB and SHB's assets decreased in 2017, the assets have increased gradually through the strategic adjustment.

Secondly, the profitability has been improved, and the growth of operating income and net profit has accelerated. In 2015, due to the fact that the five banks have just been established, all the banks except WMB are in a state of loss. Among them, the loss of WB reached 580 million yuan. With the continuous improvement of the banks, the bank's profit level has increased rapidly. The average growth rate of operating income of all banks is higher than $40 \%$, and the net profit has also exceeded 100 million yuan. The WB performed well, its operating revenue and net profit increased to 14.87 billion yuan and 3.95 billion yuan respectively in 2019. However, the SHB's net profit has decreased.

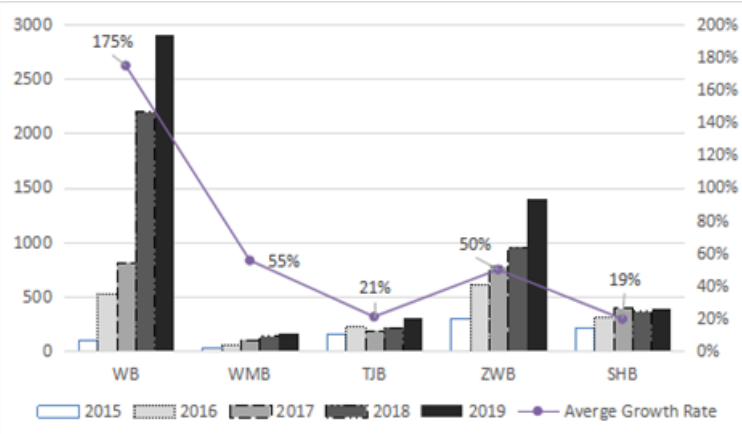

Figure 1 Change of asset scale(Unit:100 million yuan)

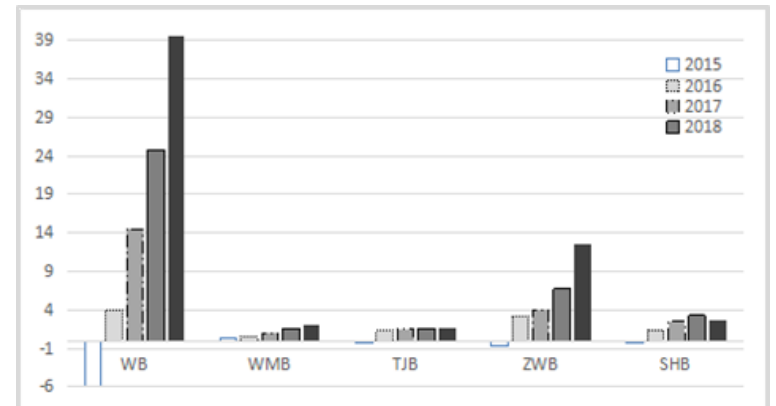

Figure 2 Change of net profit(Unit:100 million yuan)

Finally, the overall risk defense ability of banks is strong and the risk level is low. In 2019, the average non-performing loan ratio of five banks were $0.94 \%$, which was 0.92 percentage points lower than that of all banks. Among them, the non-performing loan ratio of $\mathrm{WMB}$ is only $0.03 \%$. But the non-performing loan ratio of each bank has increased in recent year, each bank should strengthen risk prevention.

It is worth noting that there is a big gap between the five private banks in terms of operation scale and profit level. The reason is the WB and ZWB are both Internet banks. They take advantage of Tencent and Alibaba's customer resource and Internet technology to create characteristic products. So they can break the policy restriction of "one bank, one store" of other three banks and realize rapid expansion.

\section{MEASUREMENT OF OPERATIONAL PERFORMANCE}

\subsection{Sample index and data selection}

In order to make a more comprehensive analysis of operational performance, this paper selects index from five aspects, including risk prevention, debt repayment, 
asset situation, development and profitability. The specific indicators are shown in Table 1.The data is from the annual reports of each bank in 2015-2019.

Table 1. Variable index

\begin{tabular}{|c|c|c|c|}
\hline Variable & $\begin{array}{c}\text { Symb } \\
\text { ol }\end{array}$ & Variable & $\begin{array}{c}\text { Symb } \\
\text { ol }\end{array}$ \\
\hline $\begin{array}{l}\text { Return on } \\
\text { Equity }\end{array}$ & $X_{1}$ & Equity Ratio & $X_{8}$ \\
\hline $\begin{array}{c}\text { Net Asset } \\
\text { Growth Rate }\end{array}$ & $X_{2}$ & $\begin{array}{l}\text { Capital } \\
\text { Adequacy } \\
\text { Ratio }\end{array}$ & $X_{9}$ \\
\hline $\begin{array}{l}\text { Total Assets } \\
\text { Growth Rate }\end{array}$ & $X_{3}$ & $\begin{array}{c}\text { Core Capital } \\
\text { Adequacy } \\
\text { Ratio }\end{array}$ & $X_{10}$ \\
\hline $\begin{array}{c}\text { Net Profit } \\
\text { Growth Rate }\end{array}$ & $X_{4}$ & $\begin{array}{l}\text { Provision } \\
\text { Coverage }\end{array}$ & $X_{11}$ \\
\hline $\begin{array}{c}\text { Cost-to- } \\
\text { income Ratio }\end{array}$ & $X_{5}$ & $\begin{array}{l}\text { Bad Loan } \\
\text { Ratio }\end{array}$ & $X_{12}$ \\
\hline Current Ratio & $X_{6}$ & $\begin{array}{c}\text { Asset Profit } \\
\text { Ratio }\end{array}$ & $X_{13}$ \\
\hline $\begin{array}{c}\text { Loan-to- } \\
\text { deposit Ratio }\end{array}$ & $X_{7}$ & & \\
\hline
\end{tabular}

\subsection{Factor analysis}

\subsubsection{Factor Score Calculation}

Firstly, considering the different influence direction of different indicators on operational performance, we calculate the reciprocal of $\mathrm{X}_{5}, \mathrm{X}_{8}$ and $\mathrm{X}_{12}$. Then, Using $\mathrm{Z}$-score method to standardize the data.

Factors with eigenvalues higher than 1 in 2019 are listed in Table 2. And their cumulative contribution rate of variance is $100 \%$. Therefore, these four factors are used as principal component factors instead of the original indicators, and they are recorded as $F_{1}, F_{2}, F_{3}$ and $\mathrm{F}_{4}$ respectively.

Table 2. Variable index

\begin{tabular}{c|ccc}
\hline \multirow{2}{*}{$\begin{array}{c}\text { Compositio } \\
\mathbf{n}\end{array}$} & \multicolumn{3}{|c}{ Initial Eigenvalue } \\
\cline { 2 - 4 } & Total & $\begin{array}{c}\text { Variance } \\
(\%)\end{array}$ & $\begin{array}{c}\text { Accumulate } \\
(\%)\end{array}$ \\
\hline 1 & 5.84 & 44.92 & 44.91 \\
2 & 3.60 & 27.70 & 72.62 \\
3 & 2.18 & 16.79 & 89.41 \\
4 & 1.38 & 10.59 & 100.00 \\
\hline
\end{tabular}

The load matrix of principal component factors shows that there is a correlation between each principal component factor and the original index. $F_{1}$ has a large load on $X_{12}$ and $X_{11}$, which indicates that asset quality has an impact on performance. $F_{2}$ has large load on $X_{13}$ and $\mathrm{X}_{4}$, it shows that profitability has an effect on performance; $F_{3}$ has large load on $X_{9}$ and $X_{10}$, indicating that the risk resistance ability of assets is very important to the operation of banks; $\mathrm{F}_{4}$ has a large load on $\mathrm{X}_{6}$, which reflects that the liquidity level of bank assets affects the performance. Therefore, the four factors from $F_{1}$ to $F_{4}$ are named loan quality factor, profit factor, risk defense factor and operational efficiency factor.

Using the component score coefficient matrix to calculate the four principal component factor scores of five banks. Taking the variance contribution rate of $F_{1}$ to $F_{4}$ in Table 2 as the weight. Then we used formula 1 to calculate the comprehensive factor score of banks in 2019. Repeat the above steps to calculate the factor scores of other years. The results are shown in Table 3.

$F=0.449 F_{1}+0.277 F_{2}+0.168 F_{3}+0.106 F_{4}$

\subsubsection{Result Analysis}

The principal component factor load matrix shows that the loan quality, profitability, security and liquidity of capital have significant impacts on the operational performance of the five banks.

And Table 3 shows that: Firstly, the comprehensive factor score of WMB was 0.75 in 2015, it was higher than other banks'. The main reason is that in the early stage of its establishment, WMB strictly controlled its operating costs and created special products to increase its operating income and net profit. Since then, WMB has gradually expanded business and steadily promoted the construction of risk management organizational structure. So WMB's non-performing loan ratio is only $0.03 \%$ in 2019 . The steady growth of profits and the low level of risk make WMB perform well, and the operational performance of WMB has obtained high scores in each year. Secondly, WB's overall operation was not good in 2015, the comprehensive score is -0.83 . The reason is that WB's profit loss was serious because of the high cost in the early stage of its establishment. Then, WB made use of Internet technology and customer resource advantages to provide customers with convenient loan business, so WB's business income and net profit were improved. In 2017, the WB's operating performance is the highest. However, since 2018, the non-performing loan ratio increased year by year. So the comprehensive score of WB dropped to -0.52 in 2019. Thirdly, TJB's operational performance is at a high level due to its less loss and high asset loan quality in 2015 and 2016. Because the other investment businesses of TJB has decreased in 2017, the scale of TJB's assets has shrunk and the level of operational performance has decreased. Fourthly, the non-performing loan ratio of ZWB is always higher than that of the other four banks, indicating that the loan quality of ZWB is poor, and it has a significant negative impact on the operating performance of ZWB every year. In 2019, ZWB attaches great importance to risk management, so its capital adequacy ratio and performance level were improved. Fifthly, similar to ZWB, SHB has shown a lack of motivation in its development in the past five 
years, and its overall business performance level is low. At the same time, the operating income and net profit of SHB decreased in 2019. The reason may be that the products and services of SHB are similar to those of other financial institutions in the same region, so the competitiveness of SHB is weak and the profitability of
SHB is poor. In addition, compared with the other four banks, SHB's loan quality is poor and the nonperforming loan ratio is higher, so SHB's comprehensive factor score is low, and SHB's overall operational performance level is low.

Table 3. Ranking of comprehensive factor score and average score of five banks in 2015-2019

\begin{tabular}{cccccccc}
\hline Bank & $\mathbf{2 0 1 5}$ & $\mathbf{2 0 1 6}$ & $\mathbf{2 0 1 7}$ & $\mathbf{2 0 1 8}$ & $\mathbf{2 0 1 9}$ & Average score & $\begin{array}{c}\text { Comprehensive } \\
\text { ranking }\end{array}$ \\
\hline WB & -0.83 & -0.67 & 0.65 & 0.36 & -0.52 & -0.202 & 3 \\
WMB & 0.75 & 0.92 & 0.52 & 0.74 & 0.89 & 0.764 & 1 \\
TJB & 0.08 & 0.27 & -0.16 & -0.02 & -0.07 & 0.02 & 2 \\
ZWB & -0.29 & -0.59 & -0.42 & -0.44 & 0.14 & -0.32 & 5 \\
SHB & 0.30 & 0.07 & -0.59 & -0.63 & -0.43 & -0.256 & 4 \\
\hline
\end{tabular}

\section{CONCLUSION}

This paper used the financial data from 2015 to 2019 to make a comparative analysis of the five banks' operational performance. The results show that: First, the loan quality has a high impact on the operating performance of private banks, while the profitability, security and liquidity of capital have a significant impact on the level of operating performance; second, WMB has achieved outstanding performance in the development of the past five years. Third, the nonperforming loan ratio of $\mathrm{WB}, \mathrm{TJB}, \mathrm{ZWB}$ and SHB continued to rise, so the operational performances of banks have decreased significantly; Fourth, the overall performance of ZWB and SHB is low.

According to the above conclusions, this paper provides some suggestions: Firstly, controlling the loan quality and improving the risk prevention system are the foundation to ensure the steady development of private banks. Banks should speed up the construction of risk control team. They should also do a good job in loan approval and monitoring. Secondly, in order to improve the profitability, banks can investigate the financial service needs of customers in their regions, and innovate products according to different needs, so as to make the products more targeted; Finally, private banks should make full use of Internet technology and other advantages, through advertising and other ways to increase public recognition, so as to provide a customer base for the bank's business development.

\section{REFERENCES}

[1] Wang Gang, Wu Fei. Investigation and policy recommendations on the operation of the first batch of pilot private banks in China[J]. Economic Review, 2016 (12): 96-102 (in Chinese)

[2] Zhao Wenqian. Development status and Countermeasures of private banks in China [J]. Market Research, 2020 (01): 46-47 (in Chinese)
[3] Li Lihua. Development mode and strategy selection of Internet private banks [J]. Contemporary Education Practice and Teaching Research, 2020 (04): 21-22 (in Chinese)

[4] Li Hao. Research on the difficulties faced by the development of private banks and the path of regulatory reform $[\mathrm{J}]$. Hainan Finance, 2019 (03): 26-31 (in Chinese)

[5] Xu Yishan. Difficulties and Countermeasures of bank financing for private small and micro enterprises $[\mathrm{J}]$. Enterprise Reform and Management, 2020 (11): 100-101 (in Chinese)

[6] Liu Yu. Difficulties and Countermeasures of financial risk management of private banks [J]. Accounting Study, 2020 (01): 24-25 (in Chinese)

[7] Serpil C., Altan C. and Suleyman B. K., Prediction of commercial bank failure viamultivariate statistical analysis of financial structures[J]. The Turkishease, European Journal of Operational Research, 2005, 166.

[8] Liu Xiaolei. Analysis of the operating performance of China's Listed Commercial Banks Based on factor analysis [J]. Mall modernization, 2018 (22): 121-124 (in Chinese)

[9] Susan M. M., Ray J. P. and Kiran V., Economic Value Added, Future Accounting Earnings, and Financial Analysts'Earnings Per Share Forecasts[J]. Review of Quantitative Finance and Accounting, 2011, 1: 59-73.

[10] Jelena S. and Evelina M., The evaluation of bank performance using a multicriteria decision making model: a case study on Lithuanian commercial banks[J]. Technological and Economic Development of Economy, 2012, 18(1).

[11] Barak Edelstein, Joseph C. Paradi, Adria Wu, Petty Yom, Bank Branch Grouping Strategy, an Unusual DEA Application[J]. Journal of Service Science and Management, 2012, 5, 355-364. 